Creative Commons User License: CC BY-NC-ND

Abstracted by: EBSCOhost, Electronic Journals Service (EJS),

Google Scholar, Journal Seek, Scientific Commons,

Food and Agricultural Organization (FAO), CABI and Scopus
Journal of Agricultural Extension

Vol. 24 (1) January, 2020

ISSN(e): 24086851; ISSN(Print); 1119944X

http://journal.aesonnigeria.org

http://www.ajol.info/index.php/jae

Email: editorinchief@aesonnigeria.org

\title{
Community Participation and Sustainability of the Community and Social Development Projects in Kwara State, Nigeria
}

https://dx.doi.org/10.4314/jae.v24i1.14

\section{Yusuf, Olayinka Jelili}

Department of Agricultural Economics and Extension Services, Kwara State University, Malete, Nigeria

olayinkaj.yusuf@kwasu.edu.ng; +234(0)8067105522

\section{Adekunmi, Adesoji Oyeniyi}

Department of Agricultural Economics and Extension Services, Ekiti State University, AdoEkiti

adesoii.adekunmi@eksu.edu.ng; +234(0)8034265824

\section{Ayanda, Ibrahim Folorunsho}

Department of Agricultural Economics and Extension Services, Kwara State University, Malete, Nigeria

iayanda@yahoo.com; +234(0)8033737391

\begin{abstract}
The study identified development projects instituted under the CSDP, ascertained extent of community participation at every critical stage of the project and determined whether perceived sustainability of CSDPs was significantly related to community participation in Kwara State. Multistage sampling procedure was used to select 120 respondents for the study. Structured interview schedule was used for data collection while percentages, mean scores and the Pearson Product Moment Correlation (PPMC) were used for data analysis. Community participation in organization of and attendance at meeting and financial contribution was high with weighted mean scores of 1.62 and 1.50, respectively, but low in most other project components. There was significant but positive relationship between age ( $r=$ 0.25), estimated monthly income $(r=0.26)$ and perceived sustainability ( $r=$ 0.31 ) and community participation at $p \leq 0.01$. In contrast, there was significant but inverse relationship between community participation and number of project executed $(r=-0.25)$. In conclusion, extent of community participation was low in most project components and community participation tended to increase with higher monthly income, fewer number of projects individual participated in, and higher perceived sustainability of the projects. Stakeholders of the CSDPs at government's and grassroots' levels should allow for more engagement of the people at all components of the CSDPs and the local communities should take on fewer projects at a time so as to enhance community participation.
\end{abstract}

Key words: Community participation, CSDP, participatory development, perceived sustainability, gender balance 
Creative Commons User License: CC BY-NC-ND

Abstracted by: EBSCOhost, Electronic Journals Service (EJS),

Google Scholar, Journal Seek, Scientific Commons,

Food and Agricultural Organization (FAO), CABI and Scopus
Journal of Agricultural Extension

Vol. 24 (1) January, 2020

ISSN(e): 24086851; ISSN(Print); 1119944X

http://journal.aesonnigeria.org

http://www.ajol.info/index.php/jae

Email: editorinchief@aesonnigeria.org

\section{Introduction}

Bottom-top or participatory approach to development intervention is indispensable to the success and sustainability of any project. The focus on participation in development, in the past few decades, is as a result of reaction against large-scale top-down development projects (Mansuri and Rao, 2012). Also, participation is considered an important component for securing community people's decisionmaking and providing equitable opportunities amongst them (Islam, 2014, 2015).

Community participation, wherein beneficiaries are involved in critical stages of the development interventions is increasingly gaining attention in global development discourse. Aga, Noorderhaven \& Vallejo (2017) described community participation as a process which entails active involvement in development projects of a specific groups, with shared needs living in a defined geographic area. Community participation enables the intended beneficiaries to partake in key decision-making for the project and gives opportunity for local people to have control of the project (Madajewicz, Tompsett, \& Habib, 2014; Riddell, 2013). Indeed, local participation has been proposed as a method to achieve a variety of goals, including sharpening poverty targeting, improving service delivery, expanding livelihood opportunities, and strengthening demand for good governance (Mansuri and Rao, 2012).

Summarizing review of several literatures, Monaledi (2016) documented benefits of community participation to include: building capacity of among beneficiaries, increased project efficiency, incorporation of local knowledge, greater sustainability of the project and better functioning of the community. Furthermore, from hundreds of examples of interventions examined by Mansuri and Rao (2012), including some world bank projects aimed at promoting participatory development, the authors reported that communities tend to express greater satisfaction with decisions in which they participate, even when participation does not change the outcome or when outcomes are not consistent with their expressed preferences.

The foregoing illustrate that people having a voice in collectively identifying and meeting their own needs is sine qua non to participatory development. Many poverty reduction projects in developing countries were not sustainable because of their supply-driven and top-down nature, which neglected community partnership and ownership of development projects.

The Community and Social Development Project (CSDP) is a World Bank Assisted Project for poverty reduction intervention aimed at sustainably increasing access of the poor to social infrastructure and natural resources. It employs the Community Driven Development (CDD) approach which has become a key strategy used by both government and development assistance programmes and wherein the poor takes the 'driver's seat' in decision making in its service delivery (Obar, Adekoya \& Nkwocha, 2017)

The sustainability of any community project, to a large extent depends on the participation of the members of the community (Mahama and Badu-Nyarko, 2014). 
Creative Commons User License: CC BY-NC-ND

Abstracted by: EBSCOhost, Electronic Journals Service (EJS), Google Scholar, Journal Seek, Scientific Commons,

Food and Agricultural Organization (FAO), CABI and Scopus
Journal of Agricultural Extension

Vol. 24 (1) January, 2020

ISSN(e): 24086851; ISSN(Print); 1119944X

http://journal.aesonnigeria.org

http://www.ajol.info/index.php/jae

Email: editorinchief@aesonnigeria.org

Project sustainability relate to both the behaviours of end users towards sustaining the operations of the project and the continuation of the project services after its completion; thus, very critical for the long term success of development projects (Oakland, 2015; Aga et al., 2017). Sustainability of development projects is often a big problem in developing countries including Nigeria, where several pockets of abandoned interventions abound in rural communities, which may be linked to poor community participation. Unlike previous government development interventions, it is anticipated, a priori, that community driven nature of the CSDP would engender sustainability of these projects.

However, there exist few empirical studies (Adesida \& Okunlola, 2015; Monaledi, 2016; Obar et al., 2017; Aga et al., 2017) that investigated the association between community participation and sustainability of development projects. Specifically, none of such studies were found by these authors with respect to the CSDPs in Kwara State. This study, therefore, aimed at empirically investigating the relationship between community participation and sustainability of rural development projects using the CSDPs in Kwara State, Nigeria, as a point of reference.

\section{Objective of the study}

The objectives of the study were to:

1. identify development projects instituted under the CSDP in Kwara State;

2. evaluate extent of community participation in the projects; and

3. determine the relationship between perceived sustainability of CSDPs and community participation.

\section{Methodology}

Kwara State is located within the North Central geopolitical zone of Nigeria commonly referred to as the Middle Belt. It has 16 local government areas with the state capital in Ilorin. It covers an area of $36,825 \mathrm{~km}^{2}$ and regarded as the ninthlargest Nigerian state by size (wikipedia.org, 2019). The state is situated between parallels $8.9848^{\circ} \mathrm{N}$ and $4.5624^{\circ} \mathrm{E}$ with Niger State in the north, Kogi State in the east, Oyo, Ekiti and Osun States in the south and an international boundary with the Republic of Benin in the west (nigeria.gov.ng, 2019). Consisting of mostly of wooded savanna, but with forested regions in the south (Britannica.com, 2019), agriculture constitutes the main source of the State's economy. Farming is the major occupation of the people (nigeria.gov.ng, 2019)

Multistage sampling procedure was used for selecting respondents for the study. At first stage, clustering the state along senatorial zones to ensure representativeness, $25 \%$ of total number of beneficiary local government areas (LGA) in the state were randomly selected from 3 zones of the state, giving 3 LGAs. Secondly, $50 \%$ of the number of beneficiary communities in the 3 LGAs were selected giving 6 communities. At third stage, proportionate sampling was used to select 120 respondents to include the Community Project Management Committee (CPMC) 
Creative Commons User License: CC BY-NC-ND

Abstracted by: EBSCOhost, Electronic Journals Service (EJS), Google Scholar, Journal Seek, Scientific Commons,

Food and Agricultural Organization (FAO), CABI and Scopus
Journal of Agricultural Extension

Vol. 24 (1) January, 2020

ISSN(e): 24086851; ISSN(Print); 1119944X

http://journal.aesonnigeria.org

http://www.ajol.info/index.php/jae

Email: editorinchief@aesonnigeria.org

members and non-members. Interview schedule was used for primary data collection. Data collected were summarized using percentage and weighted mean scores, while the Pearson Product Moment Correlation was used for inferential deduction.

Personal characteristic related variables such as sex, educational level, indigene status, etc, were measured at nominal level while those such as age, household size and monthly income were measured at ratio level. Guided by preliminary field visit and the literature, a list of community development projects was provided for the respondents to check which amongst them were instituted or established in their community under the CSDP. Extent of community participation was operationalized by requesting respondents to check degree of their participation at different itemized stages of project life cycle on a 4-point Likert-type scale viz: 'always participated' - 3; 'sometimes participated' - 2; 'rarely participated' - 1; and 'not at all participated' - 0 . Weighted mean score (WMS) values were obtained for each stage and bench mark of 1.5 was stipulated to indicate high (i.e. above 1.5) and low (below 1.5) extent of community participation at that stage. Several indicators were used as measure of sustainability to capture its major areas identified in the literature including the social, economic and environmental aspects of sustainability, amongst others. Respondents were requested to evaluate extent to which they consider the CSDP exhibiting the characteristics/dimension of sustainability so listed on a 4-point Likert-type scale viz: 'to a large extent' - 3 points; 'to a reasonable extent' - 2; 'to a little extent' -1 and 'not at all' - 0 point. Weighted mean score values were also obtained and using a benchmark of 1.5 , values below this indicates low degree of sustainability while above indicate high.

\section{Results and Discussion}

\section{Community Social Development Projects instituted in the study area}

Table 1 shows that different projects were established under the CSDP in the study area. Prominent among these were health centre establishment $(79.2 \%)$, borehole construction (73.3\%) and construction of classrooms in schools (57.5\%). Others include rural electrification project $(34.2 \%)$, project on erosion measures $(7.5 \%)$ and construction/road rehabilitation (1.7\%). Projects related to waste management $(0.8 \%)$, drainage systems $(0.8 \%)$ and bus-stop stand/shade were very unpopular in the study area while there were no records of projects on establishment of ICT centre, lock up stores and modern oil mill.

The results indicate that a wide variety of social and physical infrastructure projects were undertaken under the CSDP in the study area. In contrast to the findings by Okereke-Ejiogu et al. (2015), projects on establishment of ICT centre, lock up stores and modern oil mill which were not at all established in Kwara State CSDP were common in Imo State. This may be linked to the fact that the CSDPs are community and people-centred which essentially focus on meeting the people's pressing needs. It is not expected that peoples' needs in society with diverse culture and different socio-cultural background would be the same. 
Creative Commons User License: CC BY-NC-ND

Abstracted by: EBSCOhost, Electronic Journals Service (EJS), Google Scholar, Journal Seek, Scientific Commons,

Food and Agricultural Organization (FAO), CABI and Scopus

http://eoi.citefactor.org/10.11226/v23i4
Journal of Agricultural Extension

Vol. 24 (1) January, 2020

ISSN(e): 24086851; ISSN(Print); 1119944X

http://journal.aesonnigeria.org

http://www.ajol.info/index.php/jae

Email: editorinchief@aesonnigeria.org

\section{Extent of Community Participation in the CSDPs in Kwara State}

Organization and attendance at meeting $(\bar{x}=1.62)$ and financial contributions $(\bar{x}=1.50)$ recorded highest mean scores, which indicate high community participation in these two areas. Other areas had mean score below 1.5 which indicate low degree of community participation. Decision on which project to execute and sharing of experience with mean score of 1.41 each followed. Sourcing of materials $(\bar{x}=1.37)$, motivation of others for group work $(\bar{x}=1.36)$, organization of fund raising $(\bar{x}=1.36)$ and identification of possible projects to undertake $(\bar{x}=1.32)$ were other areas with low of community participation.

Table 1: Community and social development projects instituted

\begin{tabular}{ll}
\hline Established projects & Percentage \\
\hline Rural electrification project & 34.2 \\
Water boreholes construction & 73.3 \\
Erosion control & 7.5 \\
Health centres & 79.2 \\
Construction of school blocks & 57.5 \\
Construction /rehabilitation of roads & 1.7 \\
Community farm project & 0.8 \\
Drainage systems & 0.8 \\
Solid waste management & 0.8 \\
Bus stop stand/shade & 0.8 \\
Information communication technology centres & 0 \\
Market structures & 0 \\
Lock up stores & 0 \\
Modern oil mill & 0
\end{tabular}

Field survey, 2019

The results show that community participation was high in organization of and attendance at meeting and financial contribution but low in most other project 
Creative Commons User License: CC BY-NC-ND

Abstracted by: EBSCOhost, Electronic Journals Service (EJS), Google Scholar, Journal Seek, Scientific Commons,

Food and Agricultural Organization (FAO), CABI and Scopus
Journal of Agricultural Extension

Vol. 24 (1) January, 2020

ISSN(e): 24086851; ISSN(Print); 1119944X

http://journal.aesonnigeria.org

http://www.ajol.info/index.php/jae

Email: editorinchief@aesonnigeria.org

components including decision making on project to execute and choice of project location, material sourcing, fund raising, amongst others. This is similar to the findings of Monaledi (2016) who reported no beneficiary participation in project identification in their study; with the projects characterized by top-down approach to decision making during the planning phase whereby the interventionists solely determined what to be done. During implementation, however, beneficiaries were primary decision makers and capacitated to make those decisions Participation in decision making by intended beneficiaries has been linked to enhanced project outcomes/sustainability which could produce projects that are not only better aligned with the preferences and needs of the beneficiaries, but are also of higher quality and more likely to be sustainable (Mansuri and Rao 2012; Aga et al., 2017)

Table 2: Extent of community participation in the CSDPs in Kwara State

\begin{tabular}{|c|c|}
\hline Stages of Project & Extent of community participation WMS \\
\hline $\begin{array}{l}\text { Identification of possible projects to } \\
\text { undertake }\end{array}$ & 1.32 \\
\hline Decision on which project to execute & 1.41 \\
\hline $\begin{array}{l}\text { Choice of project site/decision on project } \\
\text { location }\end{array}$ & 1.28 \\
\hline Decision on project design & 1.29 \\
\hline $\begin{array}{l}\text { Decision on time frame for project } \\
\text { construction }\end{array}$ & 1.31 \\
\hline Mobilization of resources & 1.31 \\
\hline $\begin{array}{l}\text { Organization of and attendance at } \\
\text { meeting }\end{array}$ & $1.62^{\star *}$ \\
\hline Organization of fund raising & 1.36 \\
\hline Financial contribution & $1.50^{\star \star}$ \\
\hline Sourcing for material resources & 1.37 \\
\hline Sharing of experience & 1.41 \\
\hline Volunteering of idea/information & 1.33 \\
\hline Volunteering of skill and expertise & 1.21 \\
\hline Volunteering in terms of manual labour & 1.23 \\
\hline Motivation of others for group work & 1.36 \\
\hline Donation of needed materials & 1.33 \\
\hline Serving in the project committees & 1.31 \\
\hline Participation in the project evaluation & 1.21 \\
\hline
\end{tabular}

**high community participation. ${ }^{*}$ WMS - weighted mean score. Field survey, 2019

Furthermore, participation in the project evaluation and volunteering of skill and expertise recorded lowest mean score of 1.21 each indicating lowest degree of community participation. The findings imply low degree of community participation in the most areas of the CSDPs. 
Creative Commons User License: CC BY-NC-ND

Abstracted by: EBSCOhost, Electronic Journals Service (EJS),

Google Scholar, Journal Seek, Scientific Commons,

Food and Agricultural Organization (FAO), CABI and Scopus
Journal of Agricultural Extension

Vol. 24 (1) January, 2020

ISSN(e): 24086851; ISSN(Print); 1119944X

http://journal.aesonnigeria.org

http://www.ajol.info/index.php/jae

Email: editorinchief@aesonnigeria.org

\section{Perceived Sustainability of the CSDPs}

Table 3 shows that indicators of sustainability such as equity $(\bar{x}=1.85)$, social cohesions $(\bar{x}=1.85)$, diversity $(\bar{x}=1.79)$ economic $(\bar{x}=1.72)$ and decision making $(\bar{x}=1.65)$ had high mean score. These indicate that the respondent highly considered that the CSDP provided equitable opportunity for all community members (equity), provided processes and structure that promotes connectedness among community member (social cohesion), promoted and encouraged diversity not discriminating non-indigene and less privilege (diversity). Also, there is openness in its decision making process (decision making) and the members of the community were willing to commit their financial resources as need be (economic).

\section{Table 3: Perceived sustainability of the CSDPs}

Indicators of sustainability

WMS $^{\star \star}$

Equity: the CSDP provide equitable opportunity and outcome for all community members

Diversity: the CSDP promote and encourage diversity i.e. non-indigene and less privilege are not discriminated against under the CSDP

Social cohesions: the CSDP provide processes systems and structure that promotes connectedness and social cohesion among community member

Quality of life: meeting basic needs and fostering good quality of life for all member of the community are utmost priority of the CSDP

Democracy: the CSDP promotes democratic processes among community member i.e. everyone has a say or less privilege are not relegated to the background due to their lowly status

Governance: the operation of the CSDP embrace open and accountable governance structures

Maturity: in the event of failure or expectation unmet, individual involved take responsibility for the inadequacies and do not resort to blame trading

Economic: the members of the community are willing to commit their financial resources as need may arise \{e.g. for repairs, renovation, etc.\} after project completion under the CSDP

Environmental: consideration for adverse environmental effects of projects are given utmost consideration under the CSDP

Decision making: openness in the decision making process.

Field survey, $2019 ;{ }^{* \star} \geq 1.5$ - high perceived sustainability

In the same vein, other indicators of sustainability which equally recorded high mean score indicate respondents highly favoured that the CSDP gave consideration for adverse environmental effects of projects (environmental); that operation of the CSDP embraced open and accountable governance structures (governance); and individuals take responsibility in the event of failure or unmet expectation (maturity). 
Creative Commons User License: CC BY-NC-ND

Abstracted by: EBSCOhost, Electronic Journals Service (EJS),

Google Scholar, Journal Seek, Scientific Commons,

Food and Agricultural Organization (FAO), CABI and Scopus
Journal of Agricultural Extension

Vol. 24 (1) January, 2020

ISSN(e): 24086851; ISSN(Print); 1119944X

http://journal.aesonnigeria.org

http://www.ajol.info/index.php/jae

Email: editorinchief@aesonnigeria.org

These findings concur with the submission of Islam (2014) and (2015) who opined that participation is important component for securing community decision making and equitable opportunities; a pre requisite to collective action and an integral element of economic improvement and social change efforts (Hoe et al., 2017).

\section{Relationship between Selected Predictor Variables and Community Participation}

Table 4 shows that there was significant and positive relationship between age $(r=$ $0.251)$, estimated monthly income $(r=0.257)$ and perceived sustainability $(r=0.312)$ and community participation at $p<0.01$. Obar et al. (2017) similarly reported positive significant relationship between age and sustainability and community participation in the CSDPs in Oyo State. They, however, reported non-significant relationship with estimated monthly income.

The results indicate that older people and those earning higher income had higher tendencies to participate in the CSDP. While older people would bring their wealth of experience to bear in the community development activities, higher income earner would be more financially comfortable to meet financial obligations that might be associated with project design and execution. The implication is that inclusion of older individual who earn appreciable steady income would engender higher degree of community participation. Similarly, the results indicate that the more the perceived sustainability of the CSDPs the higher the tendencies for community participation. This implies community participation would be enhanced with greater sustainability of the CSDPs.

Table 4: Relationship between selected independent variables and community participation

\begin{tabular}{ll}
\hline Variable & $\mathbf{r}$ \\
\hline Age & $0.251^{* *}$ \\
Estimated monthly income & $0.257^{* *}$ \\
Household size & 0.176 \\
No of project participated in & $-0.254^{* *}$ \\
Perceived sustainability & $0.312^{* *}$ \\
\hline
\end{tabular}

${ }^{* *} P \leq 0.010$. Field survey, 2019

Table 4 further shows that there was significant but inverse relationship between community participation and number of project executed $(r=-0.254)$. The negative significant relationship here indicates that people tend to participate more when fewer projects are executed at a point in time. This is plausible and sensible because multiplicity of projects executed at same time may not allow for proper monitoring and evaluation, hence decreased community participation. 
Creative Commons User License: CC BY-NC-ND

Abstracted by: EBSCOhost, Electronic Journals Service (EJS),

Google Scholar, Journal Seek, Scientific Commons,

Food and Agricultural Organization (FAO), CABI and Scopus
Journal of Agricultural Extension

Vol. 24 (1) January, 2020

ISSN(e): 24086851; ISSN(Print); 1119944X

http://journal.aesonnigeria.org

http://www.ajol.info/index.php/jae

Email: editorinchief@aesonnigeria.org

\section{Conclusion and Recommendation}

There was low extent of community participation in most project components. Also, community participation increased with higher monthly income, fewer number of projects individual participated in, and higher perceived sustainability of the projects. Stakeholders of the CSDPs at government's and grassroots' levels should allow for more engagement of the people at all components of the CSDPs and local communities should take on fewer projects at a time so as to enhance community participation.

\section{References}

Adesida, I. E. and Okunlola, J. O. (2015). Effects of community participation on the sustainability of rural infrastructure in Ondo State, Nigeria. Asian Journal of Agricultural Extension, Economics \& Sociology 7(1): 1-9

Aga, D. A., Noorderhaven, N., \& Vallejo, B. (2017). Project beneficiary participation and behavioural intentions promoting project sustainability: The mediating role of psychological ownership. Development Policy Review, 1-20.

Britannica.com. (2019, October 29). Kwara State, Nigeria. Retrieved from Britannica.com: https://britannica.com/place/kwara

Hoe, K. C., Wahab, H. A., \& Siti Hajar, A. (2017). Community participation for rural poverty alleviation: A case of Iban community in Malaysia. International Social Work, 1-19.

Islam, M. R. (2014). Improving development ownership among vulnerable people: Challenges of NGOs community empowerment projects in Bangladesh. Asian Social Work and Policy Review:, 8(3), 193-209.

Islam, M. R. (2015). Non-governmental organizations and community development in Bangladesh. International Social Work. Epub ahead of print 7 May.

Mahama, A. V., \& Badu-Nyarko, S. K. (2014). Community participation in water delivery services and sustainability in the Savelugu/Nanton Municipality, Ghana.

nigeria.gov.ng. (2019, October 29). Kwara State. Retrieved from nigeria.gov.ng: http://www.nigeria.gov.ng/index.php/2016-06-04-08-39-54/north-central/kwara

Madajewicz, M., Tompsett, A., \& Habib, A. (2014). Community participation in decisionmaking evidence from an experiment in providing safe drinking water in Bangladesh. Retrieved from https://cepr.org/sites/default/filesTOMPSETT\%20\%20Participation\%20in\%20Decision-Making\%20v4.pdf

Mansuri, G., \& Rao, V. (2012). Localizing development: Does participation work? Retrieved from World Bank website: http://documents.worldbank.org/curated/en/461701468150309553/Localizingdevelopment-does-participation-work

Monaledi, M.H.A. (2016). The relationship between community participation and the sustainability of CSR projects: The case of Grootegeluk coal mine in Lephalale 
Creative Commons User License: CC BY-NC-ND

Abstracted by: EBSCOhost, Electronic Journals Service (EJS), Google Scholar, Journal Seek, Scientific Commons,

Food and Agricultural Organization (FAO), CABI and Scopus

http://eoi.citefactor.org/10.11226/v23i4
Journal of Agricultural Extension

Vol. 24 (1) January, 2020

ISSN(e): 24086851; ISSN(Print); 1119944X

http://journal.aesonnigeria.org

http://www.ajol.info/index.php/jae

Email: editorinchief@aesonnigeria.org

Local Municipality. Mini-dissertation submitted in partial fulfilment of the requirements for the degree Magister in Development and Management at the Potchefstroom Campus of the North-West University

Okland, A. (2015). Gap analysis for incorporating sustainability in project management. Procedia Computer Science, 64, 103-109. https://doi.org/10.1016/j.procs.2015.08.469

Obar, E. E., Adekoya, A. E., \& Nkwocha, C. A. (2017). Community participation and beneficiaries' perceived sustainability of community and social development in Ibadan, Oyo State, Nigeria. Nigerian Journal of Rural Sociology, 17(1), 27-36.

Okereke-Ejiogu, E. N., Asiabaka, C. C., \& Umunakwe, P. C. (2015). Assessment of households' participation in community and social development projects (CSDP): A case study of Imo State. Advances in Research, 5(2), 1-9.

Riddell, R. (2013). Assessing the overall impact of civil society on development at the country level: An exploratory approach. Development Policy Review, 31, 371-396. Retrieved from https://doi.org/10.1111.dpr.12011

wikipedia.org. (2019, October 29). List of Nigeria States by size. Retrieved from wikipedia.org: https://en.wikipedia.org/wiki/List of Nigerian states by area\# 